\title{
Miranda
}

Revue pluridisciplinaire du monde anglophone /

Multidisciplinary peer-reviewed journal on the English-

speaking world

$18 \mid 2019$

Guerre en poésie, poésie en guerre

Neo Frontier Cinema: Rewriting the Frontier

Narrative from the Margins in Meek's Cutoff (Kelly

Reichardt, 2010), Songs My Brother Taught Me (Chloe Zhao, 2015) and The Rider (Chloe Zhao, 2017)

\section{Hervé Mayer}

\section{(2) OpenEdition}

\section{Journals}

\section{Electronic version}

URL: http://journals.openedition.org/miranda/16672

DOI: 10.4000/miranda.16672

ISSN: 2108-6559

\section{Publisher}

Université Toulouse - Jean Jaurès

\section{Electronic reference}

Hervé Mayer, "Neo Frontier Cinema: Rewriting the Frontier Narrative from the Margins in Meek's Cutoff (Kelly Reichardt, 2010), Songs My Brother Taught Me (Chloe Zhao, 2015) and The Rider (Chloe Zhao, 2017)", Miranda [Online], 18 | 2019, Online since 16 April 2019, connection on 16 February 2021. URL: http://journals.openedition.org/miranda/16672 ; DOl: https://doi.org/10.4000/miranda.16672

This text was automatically generated on 16 February 2021.

\section{c) $(1) \odot$}

Miranda is licensed under a Creative Commons Attribution-NonCommercial-NoDerivatives 4.0 International License. 


\section{Neo Frontier Cinema: Rewriting the Frontier Narrative from the Margins in Meek's Cutoff (Kelly Reichardt, 2010), Songs My Brother Taught Me (Chloe Zhao, 2015) and The Rider (Chloe Zhao, 2017)}

Hervé Mayer

1 The myth of the American frontier has provided the United States with a national mythology since the late 19th century, and has been explored most directly on screen in the genre of the Western. ${ }^{1}$ According to this mythology, the frontier is a cultural metaphor designating the meeting point between civilized territories and the savage wilderness beyond. The frontier is a vague concept, laden with imperial ideology and a history of colonization (Limerick and White 94-95). Its geographical referent is unstable and ill-defined; its historical relevance is a subject of debate among historians. But it is, in effect, a powerful metaphor to grasp the complex nature and multifaceted impact of Euro-American encounters with otherness in the colonization of North America. ${ }^{2}$ And it was promoted in the late $19^{\text {th }}$ century as the bedrock of American exceptionalism and the focal point of a national mythology. ${ }^{3}$

What cultural historians such as Richard Slotkin refer to as the myth of the frontier can be defined in simple terms as the belief that the frontier is the birthplace of the American nation, of its democratic polity, its capitalistic economy and its national identity (Slotkin 10). In other words, the frontier myth tells us that the modern American nation is born in the experience of colonization.

3 Since the emergence of narrative cinema, films have explored and challenged this myth, along with its imperialist ideological underpinnings. Westerns, as well as science fiction, war films or urban crime fictions, have obscured and exposed the central 
contradiction of a liberal nation claiming to be born out of a history of empire. Starting in the 1950s, these critical evaluations of frontier mythology also developed within what some film scholars have termed post-Westerns, generic hybrids that critically engage with the West and Western genre from a contemporary standpoint. ${ }^{4}$

Challenges to American frontier mythology have always existed in marginal as well as mainstream cinema, but they have become more overt and have drawn more critical attention since the late 1960s. The influence of auteur theory in film reception and production, ${ }^{5}$ the emergence of a marketable form of independent cinema alongside Hollywood majors (Berra 2008), along with an oppositional social and political context, explain a widespread desire to rewrite the national narrative of the frontier in ways more critical of the white man's story and more inclusive of marginal and alternative viewpoints.

5 New films exploring frontier narratives emerged that built upon and developed different strategies to achieve the rewriting of national mythology. The most important of these strategies is the foregrounding of alternative perspectives on the history of colonization. Points of view and narratives that remained largely excluded from the national imaginary as well as the historiography of the American West became the focal point of revisionist Westerns (Kitses 17-19) and the road movie genre that emerged at the same time ${ }^{6}$. The primary alternative was the Indian, whose imagined point of view had provided an opposite gaze on westward conquest since the time of silent Westerns, and whose mythical nobleness, ecological concerns and transcendentalist spirituality profoundly shaped countercultural aspirations, in films ranging from Easy Rider (Dennis Hopper, 1969) to Sunchaser (Michael Cimino, 1996). ${ }^{7}$

6 In addition to the Indian perspective, other marginal perspectives came to the foreground of revisionist Westerns and road movies, in films ranging from Thelma \& Louise $^{8}$ (Ridley Scott, 1991) to Boys Don't Cry (Kimberley Pierce, 1999) and Brokeback Mountain $^{9}$ (Ang Lee, 2005). These films (or their characters) are often torn between a criticism of triumphalist imperial mythology and an appropriation of that same mythology to reclaim the Americanness of their marginalized heroes. Minorities are included in the national imaginary by investing the cowboy ethos and frontier myth that historically produced their exclusion..$^{10}$ The case in point here is Easy Rider, with its indianized hippies who are also proto-pioneers dreaming of renewed colonial discovery. ${ }^{11}$

7 A second strategy consists in playing with the seminal trajectory of westward movement across the continent and its linear, progressive qualities. Narrative trajectories are inverted, diverted, interrupted or slowed down to the point of exhaustion. ${ }^{12}$ When the American continent has been thoroughly civilized and there are no more wild spaces to explore, characters go south to Mexico in the tradition of Stagecoach (John Ford, 1939), or north to Alaska-the female drifter of Wendy and Lucy (Kelly Reichardt, 2008). That is, unless they are stopped by the constraining forces of the law on the way as in Vanishing Point (Richard Sarafian, 1971) and Badlands (Terrence Malick, 1972) or end up wandering endlessly in the wilderness, as in The Searchers (John Ford, 1956), Vanishing Point and Gerry (Gus Van Sant, 2002).

8 Yet another strategy, also present in revisionist Westerns and road movies, consists in claiming to expose the truth behind the legend, the historical reality behind the myth. The tension between myth and history, which was a structural principle of the Western, is thus tilted in favor of history. In art cinema about the frontier since the 
1960s, this tendency has taken the form of a social-realist approach inspired by modernist European cinema. ${ }^{13}$ Rejecting mainstream Hollywood storytelling in favor of a social realist aesthetic, such films emphasize the daily difficulties of common people, the social and economic marginalization of certain populations, their destitution and plight sometimes eliciting voyeurism as much as political criticism of the failed American dream (the inbred hillbillies in John Boorman's 1972 Deliverance come to mind). This social-realist trend can be seen in a variety of films from Midnight Cowboy (John Schlesinger, 1969) and Scarecrow (Jerry Schatzberg, 1973) to Stranger Than Paradise (Jim Jarmusch, 1984), Boys Don't Cry, and more recent films like Frozen River (Courtney Hunt, 2008) and American Honey (Andrea Arnold, 2016).

9 Finally, against an imperial mindset that pictured the frontier as a racial and cultural divide, a line whose defense and impermeability ensured the purity of civilization, many films constructed the frontier as a contact zone, ${ }^{14}$ a middle ground of mixing cultures, ${ }^{15}$ a frontera or borderland, ${ }^{16}$ that is, a place of interactions and exchanges, of cooperation and mutual transformation. Since Rose O'Salem Town ${ }^{17}$ (David W. Griffith, 1910) and The Searchers, and more recently in Three Burials of Melquiades Estrada (Tommy Lee Jones, 2005), ${ }^{18}$ the frontier has been depicted as a shared, mediating space where identity is redefined as a process and where hybridity prevails.

These strategies-alternative perspectives and trajectories over the white man's westward conquest; historical or social realism over the myth of the West; and cultural dynamics over fixed identities-are not mutually exclusive. Films intending to rewrite frontier narratives usually combine them to produce fresh perspectives on a resilient national mythology. This mythology, in the words of Meek's Cutoffs screenwriter Jon Raymond, "still dictates how people envision the world" in the early $21^{\text {st }}$ century. ${ }^{19}$

11 Kelly Reichardt's Western Meek's Cutoff (2010) and Chloe Zhao's post-Westerns Songs My Brother Taught Me (2015) and The Rider (2017) are examples of films combining alternative viewpoints and narrative trajectories with historical realism and dynamic identities in a way that also engages with some of these strategies' individual limits.

Meek's Cutoff is inspired by the true story of a group of settlers on the Oregon Trail in 1845, fatally led astray by their incompetent guide Stephen Meek. In the film, the event's setting and period are maintained, but the group is reduced to three families in three wagons, and Stephen Meek is characterized as a boisterous story-teller in the talltale tradition of Mark Twain, as well as a racist, self-aggrandized Indian killer. The film starts with the crossing of a river and water supplies at their peak, only to develop into a slow, painful exhaustion of resources and bodies in the crossing of a dry, endless Great American desert. Hope comes in the form of a Native taken captive, who may or may not lead the party to water and their salvation. The dominant perspective on the story is that of the women, and specifically that of one female character, Emily Tetherow (Michelle Williams) who eventually takes up the direction of the party. Adopting a social realist aesthetic, the film is characterized by long takes, very long shots and the physicality that define contemporary slow cinema for Tiago de Luca, ${ }^{20}$ as well as its striking 1:37.1 screen format which constrains the perspective on the overwhelming landscape.

13 Songs My Brother Taught Me and The Rider were both shot on and around the Pine Ridge reservation in South Dakota. Both are about social life and culture on the present-day Oglala Sioux reservation, and both focus on young male protagonists with clear goals (escaping the reservation or getting back to rodeo). In both cases, their love for, and 
desire to protect, their younger or mentally disabled sisters lead them to renounce their dreams and embrace their family. If both films superficially embody one side of the cultural coin in the contemporary West-the Native American perspective in Songs and the poor cowboy perspective in The Rider-they depict a network of exchanges, miscegenation, acculturation, and syncretism that challenges notions of fixed and distinct political identities. The narratives of these films are denser than in Meek's Cutoff, and their pace is relatively faster, but they retain a distinct artistic quality in their elliptical editing and narration, and their blend of social realism and contemplative lyricism to explore the line between myth and history in the imaginary of the West.

Meek's Cutoff and Zhao's two films are contemporary rewritings of the frontier myth that are similar in many ways and complementary in others. Both play the mythologies of the American West against the realities and consequences of settler colonialism. Both provide alternative perspectives on the politics of empire. Both construct the Western frontier as a zone of contact, a shared space of dynamic and hybrid identities. And both challenge the original epic story of linear conquest by redefining what it means to inhabit the Great American desert. But they also differ in their preferred focus for cultural and political rewriting: Meek's Cutoffs main work centers on its alternative feminine perspective and on a deflation of the myth in its original historical terrain; Zhao's films are more about producing a postcolonial perspective on the contemporary West as a marginalized yet fascinating frontera.

\section{Realism and Female Agency in the Historical West in Meek's Cutoff}

\section{How the Social-Realist Rendering of History Deflates the Myth of the West}

Meek's Cutoff opens on a card announcing the film's title and setting in Oregon in 1845 (Fig. 1). The words are crudely sewn on a wagon canvass, framed by the silhouette of a tree and a myriad of stars, the image itself creating a childlike yet forbidding impression. This balance between innocence and fear is emphasized by the musical score, with notes that blend the harmonious with the atonal. It is made clear from this opening image that what fuels the settlers' hopes in moving west on the Oregon Trail (the mythical virgin lands of economic betterment, of moral and social renewal associated with the West) will also be the cause of their physical and psychological downfall. With this opening, Meek's Cutoff indicates that it will converse with a tradition of films that presented the American desert as a puritan wilderness, an obstacle to the forces of civilization, and a source of corruption rather than of redemption for the civilized soul. A haunting hypotext to Reichardt's film is The Searchers, whose main character Ethan Edwards is corrupted by the savagery of the frontier. Other imagery that comes to mind includes the teeth-like rock formations framed by ominous sounds in the opening of The Hills Have Eyes (Wes Craven, 1977), as well as the opening shot of There Will Be Blood (Paul Thomas Anderson, 2007), with the same grinding strings evoking the demonic character of the desert. 
Fig. 1

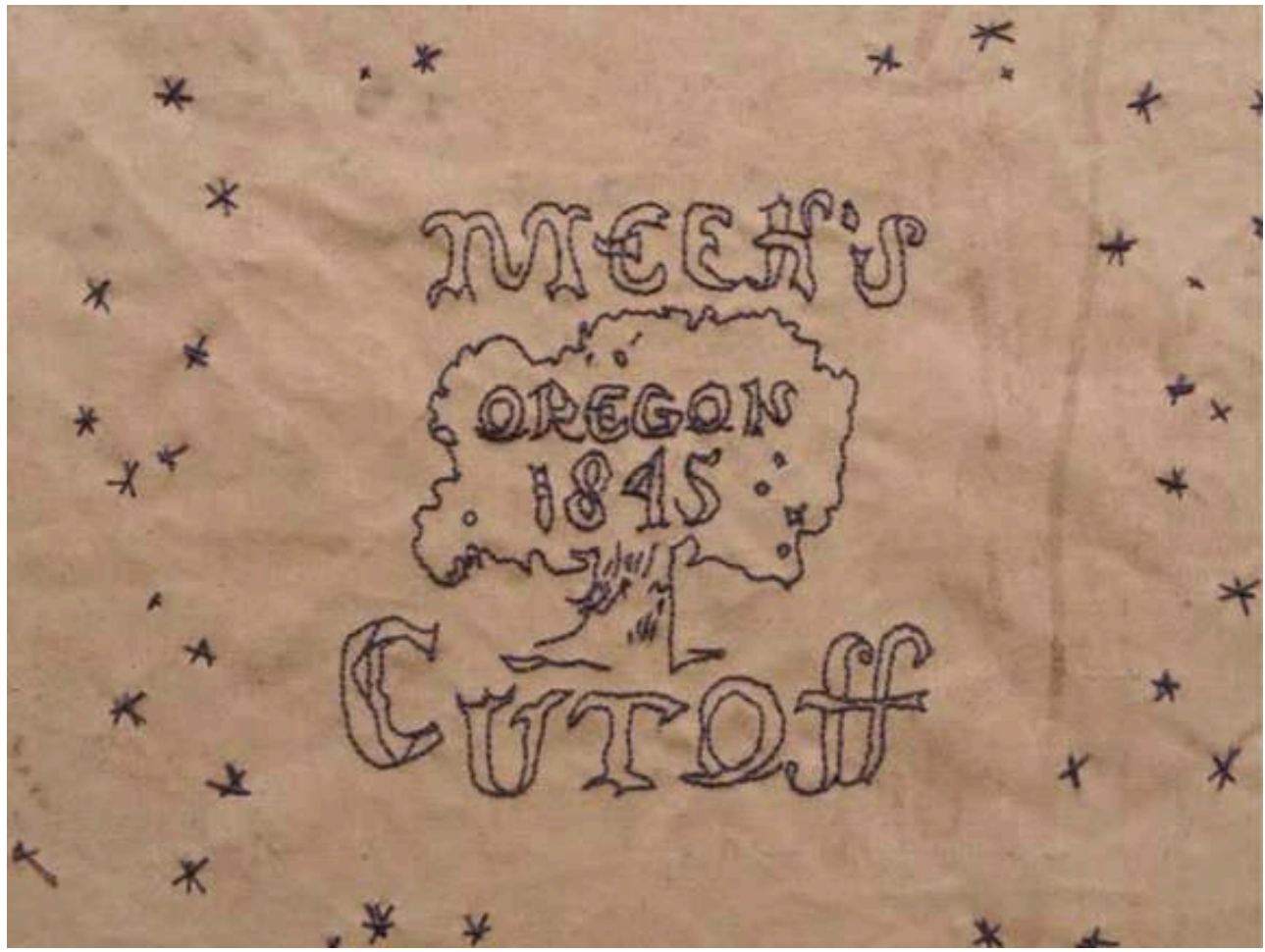

Opening card mixing innocence and fear.

The tension between the innocence of myth and the violence of history is tipped towards the latter by the first shot, which establishes the realist style and distant but constricted viewpoint on the characters' westward (leftward) journey (Fig. 2). All the elements that traditionally make up the spectacular, epic form of the Western and contribute to the triumphalist myth of westward conquest-widescreen format, open vistas, swelling music, sweeping camera movements, engaging action and dialogues, forward-driven narrative-are stripped down, leaving the viewer with the prosaic, raw and sometimes painful reality of settler colonialism. Meek's Cutoff's realism is resolutely historical, informed not only by careful attention to costume and props (as is often the case in more mainstream historical films), but also by primary sources such as $19^{\text {th }}$ century settlers' diaries and journals. ${ }^{21}$ The story focuses on the daily routine of life on a wagon journey, the repetition of alienating and arduous tasks to ensure survival, from grinding coffee and kneading bread to building a fire or finding water, with inspiration drawn by director Reichardt from early docudramas films like Nanook of the North (Robert Flaherty, 1922). ${ }^{22}$ 
Fig. 2

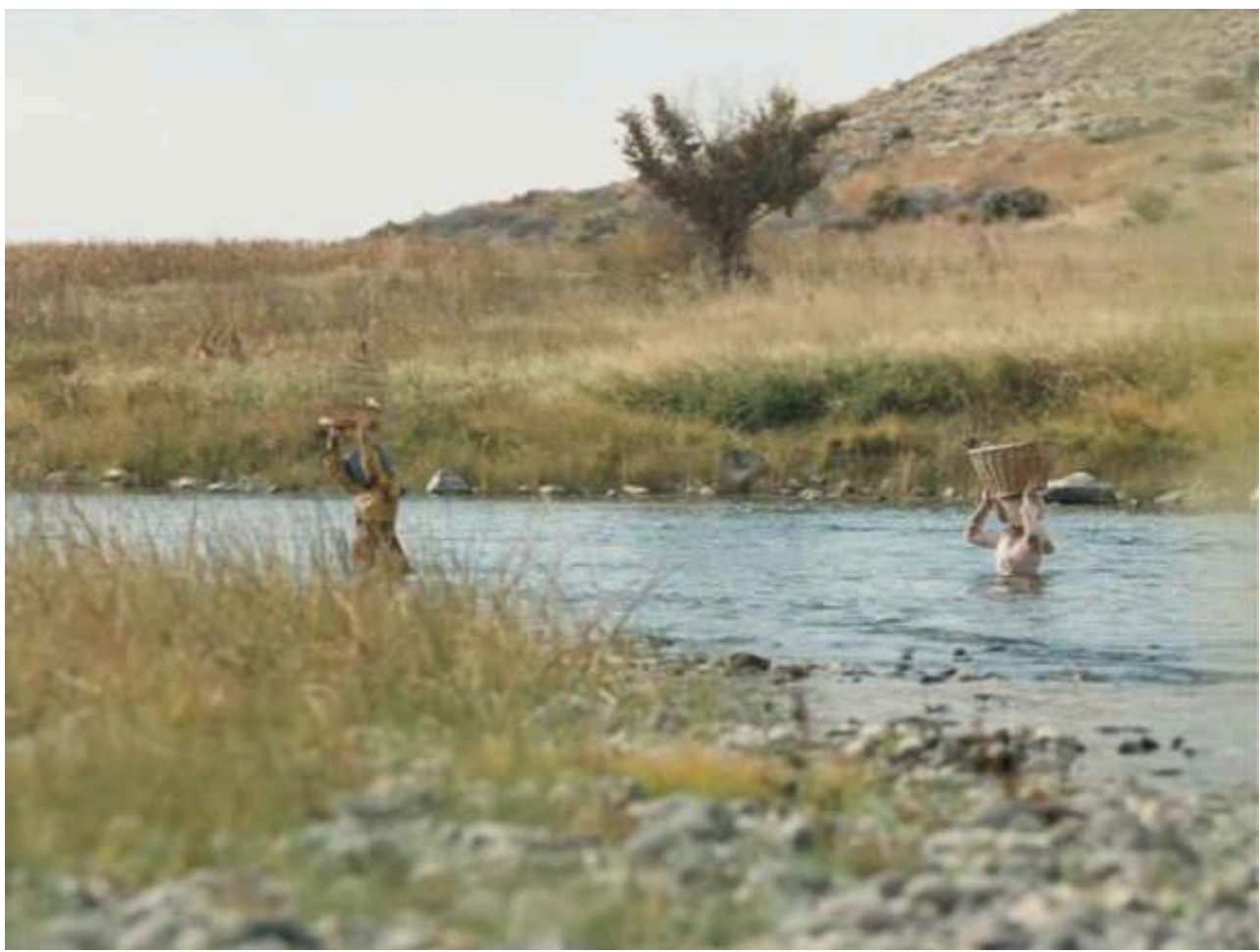

Distant but constricted viewpoint on the characters' westward (leftward) journey.

17 The slow depletion of water supplies and gradual exhaustion of the characters are mirrored in the absence of spectacular features: the limited film format, minimalist narrative, sparse dialogue, music and action, and slow pace (with long takes of 10 to 30 seconds), refuse the easy pleasures of mainstream cinema and force upon the viewer the slow progression of an obstinate wandering through nothingness, with no guarantee of ever arriving somewhere. Some critics (Dan Kois) complained about how exhausting the film was, probably out of cultural fatigue at having to labor through yet another scarcely rewarding art film (Kois 2011), and Reichardt's style has often been described as dry and anti-sensualist. In Meek's Cutoff, however, it serves to express a sense of the consuming dimension of the characters' journey.

The relative absence of music emphasizes the isolation of the characters in the great void and desert silence surrounding them. But the consequent foregrounding of foley sounds also serves to transform the familiar tones of rolling wagons into the foreboding fracas of a thunderstorm. The creation of a sense of alienation from what is familiar (both in the viewer's common perception of reality and generic expectations regarding the Western) is a central strategy of the film. This sense of alienation is heightened by the ambiguous situation of the viewer, who is positioned uncomfortably close to the characters' plight yet never given access to their inner lives. The bonnets and beards hinder direct access to faces, which remain often distant, decentered or turned away-this is notably the case in the introducing shots (Fig. 3). They are enveloped in an air of mystery, which invites viewers to actively scrutinize the screen surface for meaning, thus mirroring the characters' own sense of loss and search for redemptive signs on the blank surface of the desert. 
Fig. 3

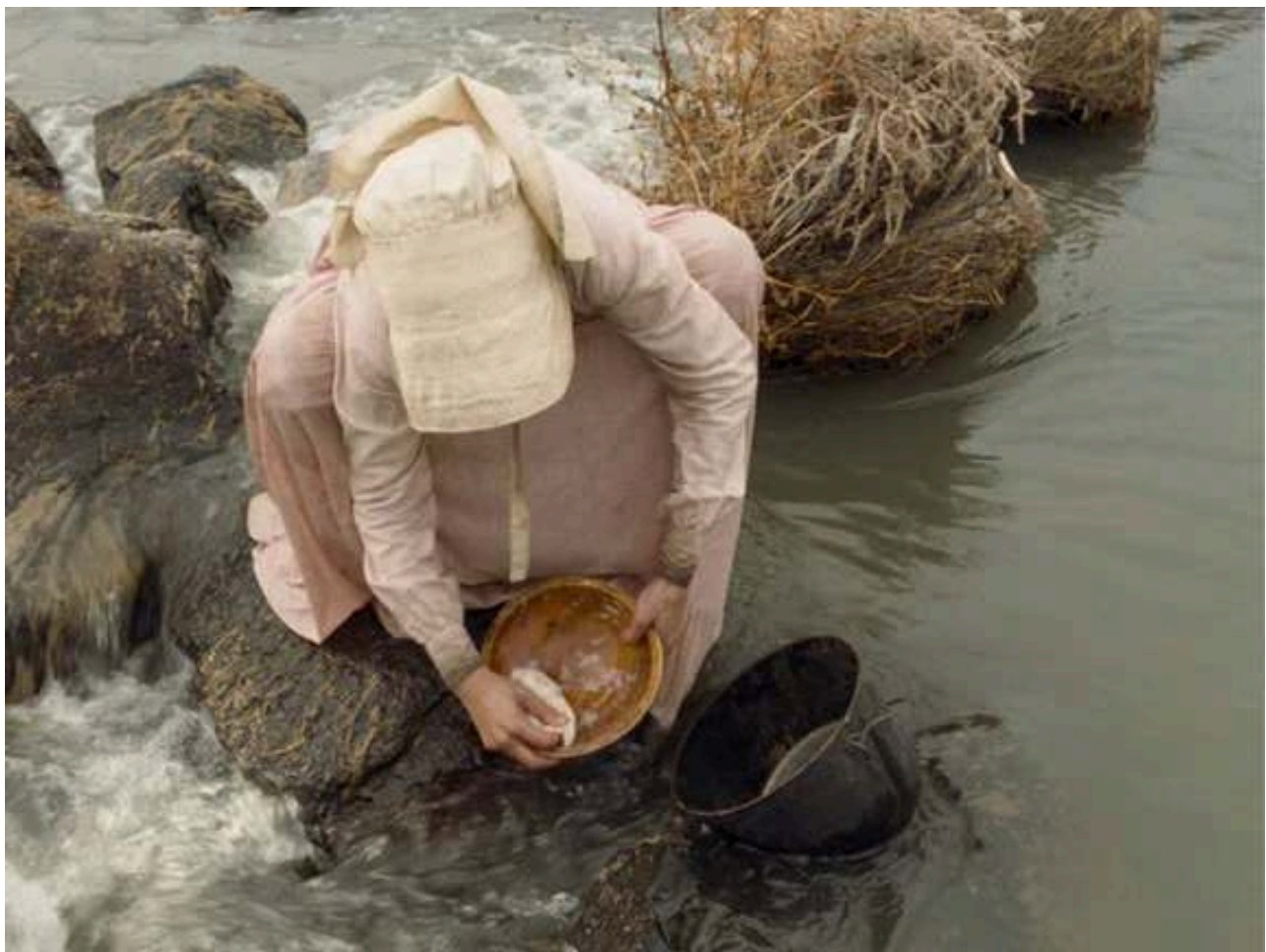

Faces remain often distant, decentered or turned away; Emily's introducing shot.

The monotonous landscape, often filmed in static shots and left unmoved by the passing of the characters, remains indifferent to human suffering and the futile scheme of Western colonization. Its barrenness, emphasized by a low positioning of the camera that cuts off western skies, belies any hope of wealth and betterment in migrating west, while its overwhelming presence, desperately unbounded in the narrow screen format, works to further alienate the characters from their quest and themselves, their purpose lost and sound mind altered to a trancelike state. One scene (Fig. 4) suggests Victor Sjöström's The Wind (1928), in which the main female character played by Lillian Gish loses her sanity to the desert wind (White 224). 
Fig. 4

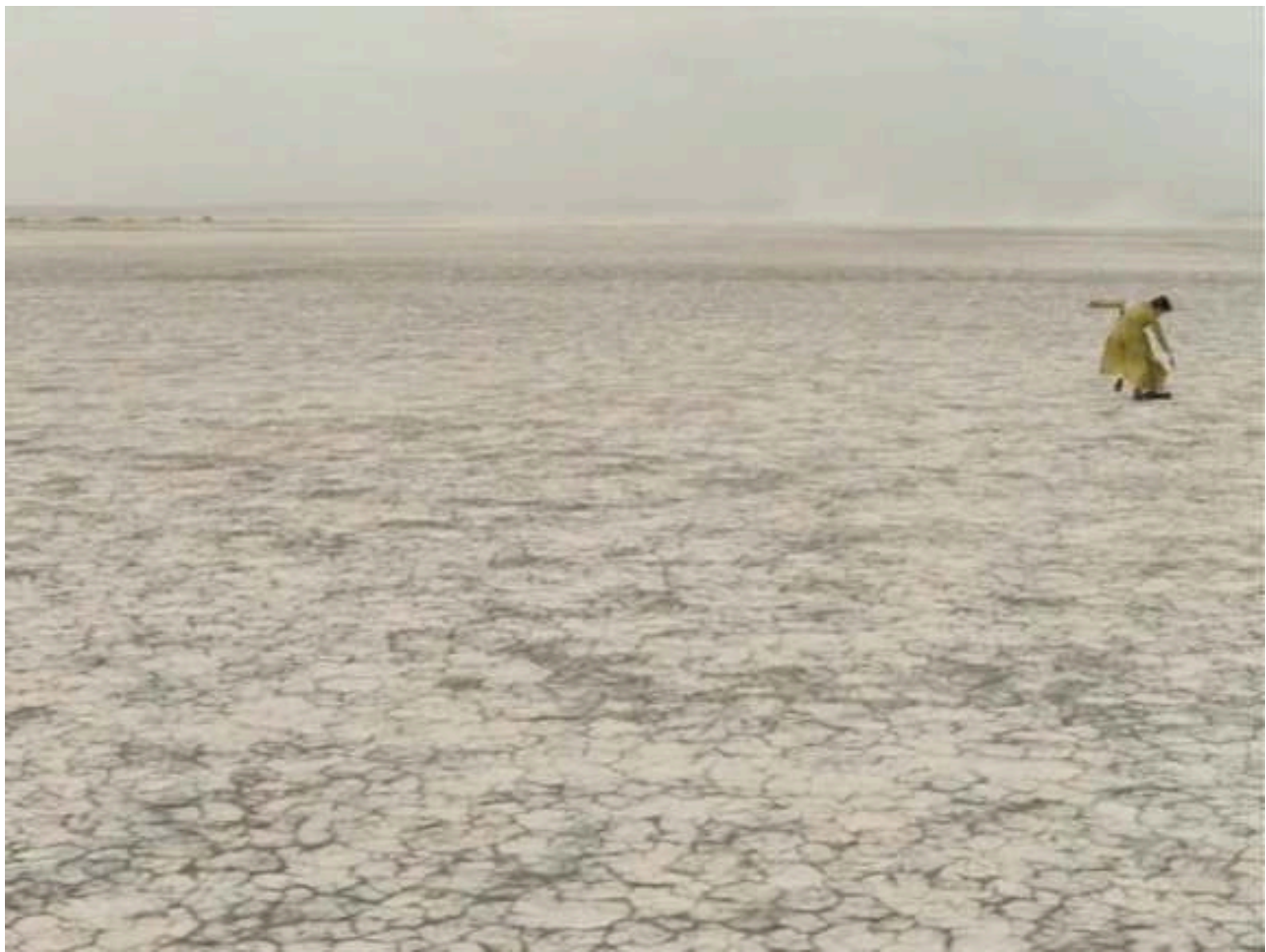

Running after one's bonnet in the desert wind

In such a dry, unblinking take on the unsettling routine of westward migration, even the sunset cinematography, usually associated with the triumphant direction of Manifest Destiny or the transcendentalist ethos of a sacred landscape, is turned into symbolic torture and the promise of death, with the backlit, dark silhouettes appearing to be lashed by brutal lens flares (Fig. 5), as Elena Gorfinkel has noted (130). With the magic-hour light turned into a threat, every element of mythical dimension is deflated, the story reduced to the individual scale of micro-history and the inglorious experience of settlers, visionaries or fools, on a strange continent. 
Fig. 5

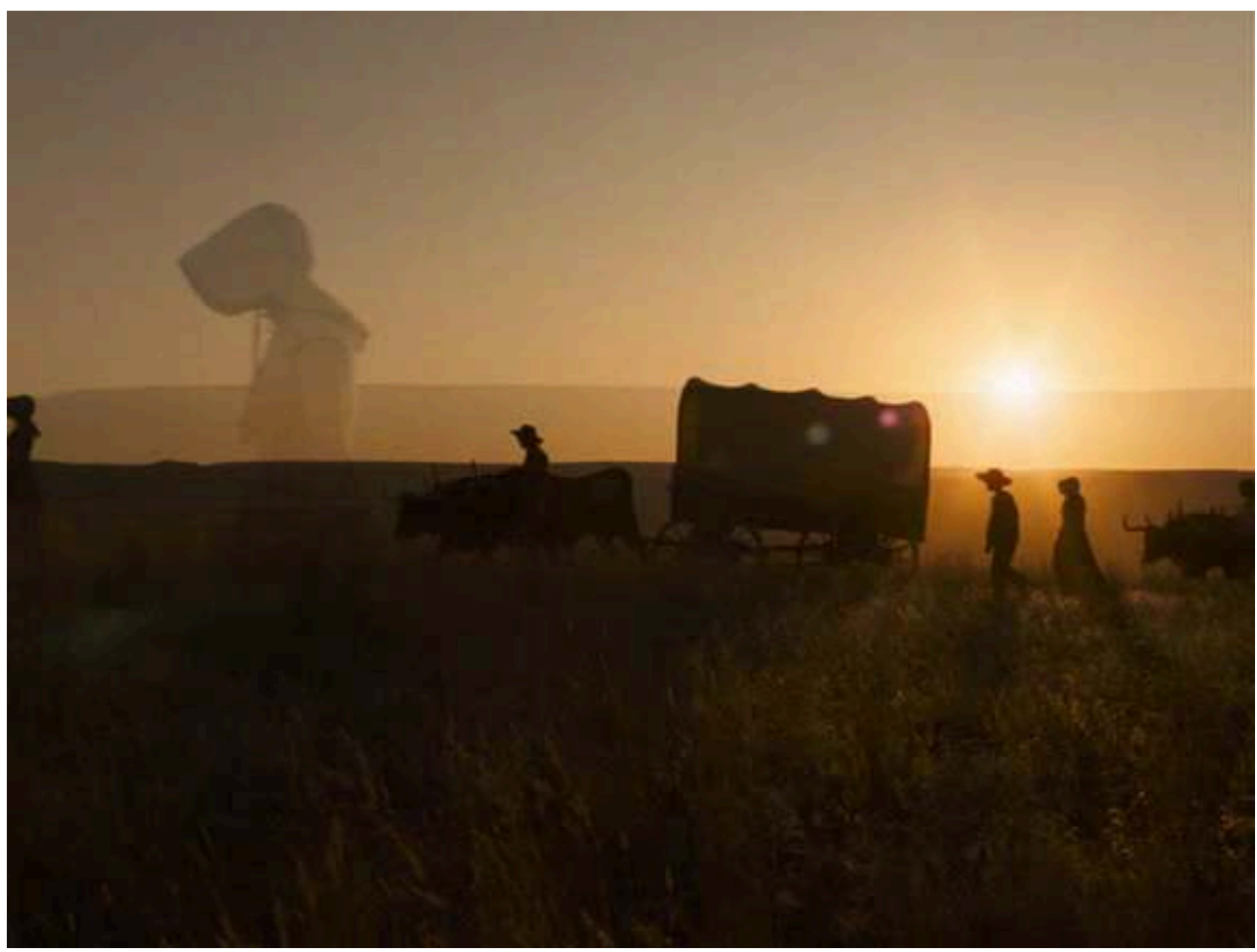

The backlit, dark silhouettes in the sunset appear to be lashed by brutal lens flares.

\section{An Alternative Trajectory to Westward Conquest}

The dissolves in the sunset sequence point to a specific construction of cinematographic time and space that belies any notion of progression. Borders between moments and places are blurred in a seamless continuum; the dissolves between sequences are dilated to emphasize the absence of starting or ending point in a scene (see for instance the end of the opening sequence). This continuum is heightened by the atonal music, which refuses the slightest form of melodic line and embraces instead a kind of shapeless atmosphere. Along with the absence of time boundaries, the slow pace and repetitive patterns of the narrative can be added to the list of elements resisting the sense of linear progression.

Progress in time is undermined just as it is in space. In the opening title, the film's subject (the tragic historical event known as Meek's Cutoff), a central narrative element (the hope for water evoked by the tree and stars) and final image (the tree) are all already established, defusing any idea of narrative progression from beginning to end, just as the immediate recognition that the characters are "lost" in the introducing sequence-a character carving the word on a log-forestalls any linear westward trajectory. By the time the film has reached its' concluding fade-out, no tangible progress has been made, and the characters and viewers have no idea whether they are ever closer to a resolution than when they started off. The long shots of characters walking in the landscape, virtually immobile in the frame, emphasize the absence of progression in spite of their movements. Though it starts with a leftward trajectory, Meek's Cutoff ultimately wanders off in circular movements which seem to lead to quasistasis. 


\section{A Limited Perspective on Colonization}

\section{Fig. 6}

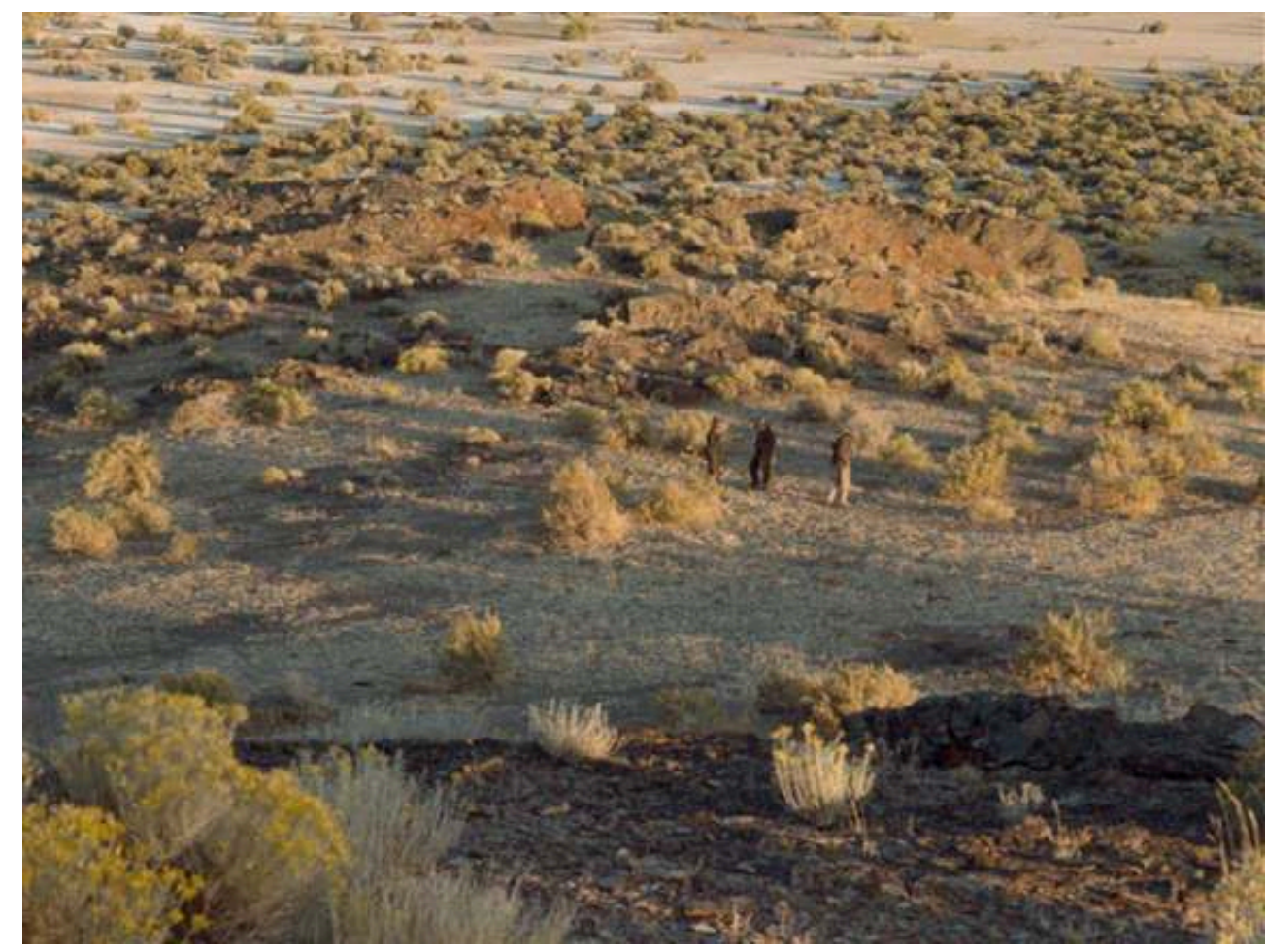

Observing male decisions from the distance.

There is a clear gendered hierarchy at work on the wagon trail, which is later contested by Emily Tetherow's superior clarity as to the predicament of the party and true nature of their guide. Indeed, Stephen Meek, the archetypal Western hero, proves to be nothing but a useless, loudmouth trickster. And while the men show signs of vulnerability and pusillanimity, the women do most of the daily work and use rifles in decisive ways, to alert the men when a Native is seen and later to protect the Native from the racist fear of Meek (Fig. 7). 
Fig. 7

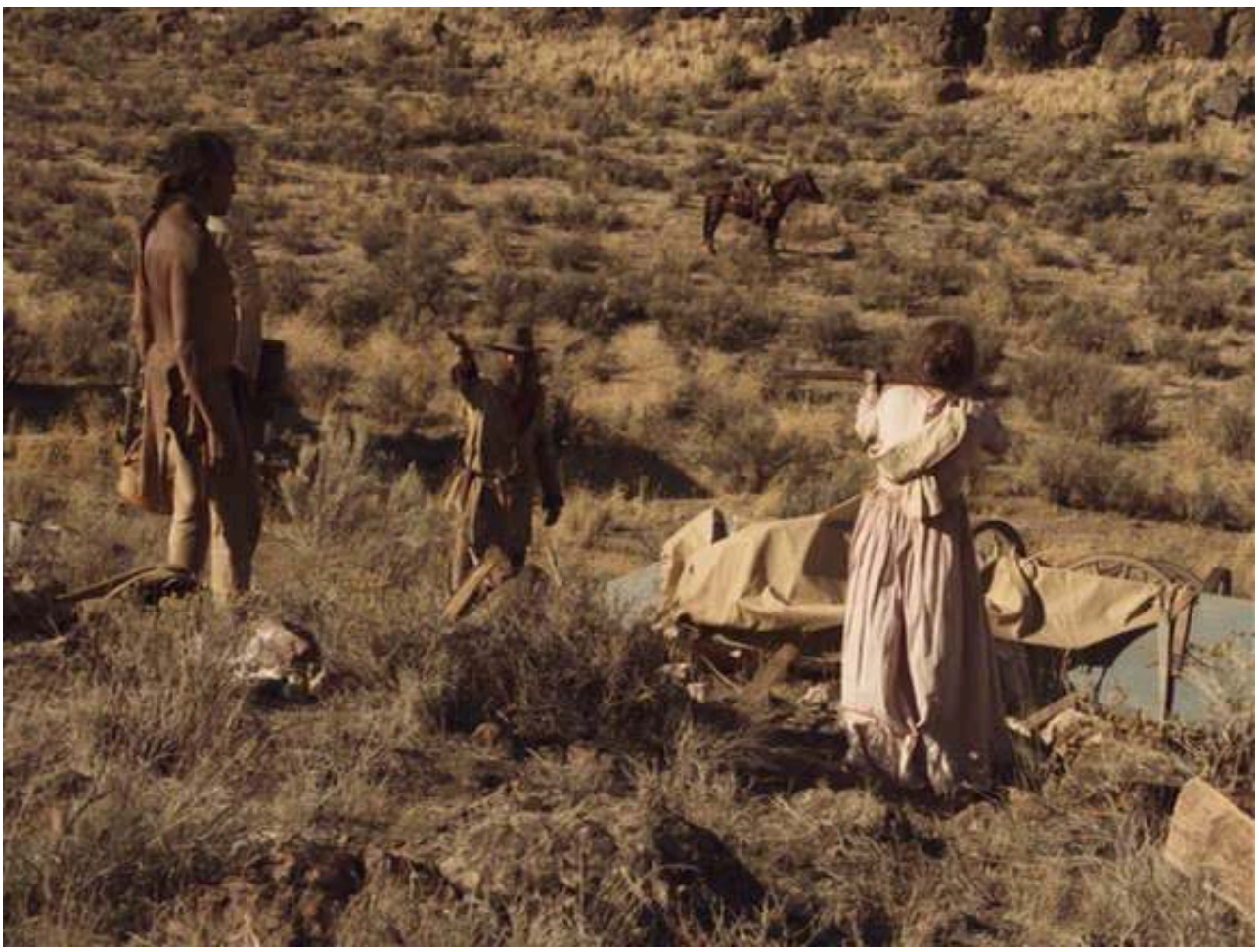

Emily protects the Native from the racist fear of Meek.

Although such an alliance of Native and female clout eventually reverses the white man's domination, when Meek yields command of the party to Mrs Tetherow and the Indian in the ending sequence, the film never idealizes such alliance but instead emphasizes the women's, and particularly Emily's, participation in the colonizing scheme. As Patricia White convincingly argues, such recognition of the white woman's active position within the framework of colonial enterprise signals the refusal to establish the film's subaltern perspective as a universal counter-narrative to the white man's story (224). Such universal pretention would only suppress the multiplicity of other subaltern narratives on the history of colonization and reproduce the oppression and erasure of imperial narration. The characterization of Emily is a clear acknowledgement of this: she may have less power than the men, but she is nonetheless privileged for being white and embraces that privilege in expressions of casual racism. At one point, she complains about "working like niggers, once again," while at another, she frowns upon Meek for practicing miscegenation with Indians. Once the Native is captured and taken along, women label him "a man-child" and make racist comments like "they don't think of life the way we do." Emily even goes so far as to give the him a lesson in civilization: "You can't imagine what we've done, the cities we've built," even though the claim sounds hollow in the midst of such a barren landscape. Emily provides help and protection to the Native not out of humanistic sentiment, but out of interest ("I want him to owe me something."). The creation of a debt, a practice that historically served the subjugation of Native Americans, is here performed by women.

Meek's Cutoff aims not so much to rewrite the history of the American West as to acknowledge the limitations of any such history. The film format encloses the 
perspective on the infinite West, just as the women's perspectives are framed and limited by their bonnets. Emily eventually assumes the leadership of the party, but even then, when she is seen deciding on whether or not to continue following the Indian, her gaze on the "savage" is obstructed and reframed by the branches of a halfdead tree, whose virtual apparition in the concluding sequence may or may not be a sign of salvation (Fig. 8). One is tempted, as White argues (224), to see in this thematization of limited perspectives the white female director's sense of her own particular viewpoint when shooting the history of the West.

Fig. 8

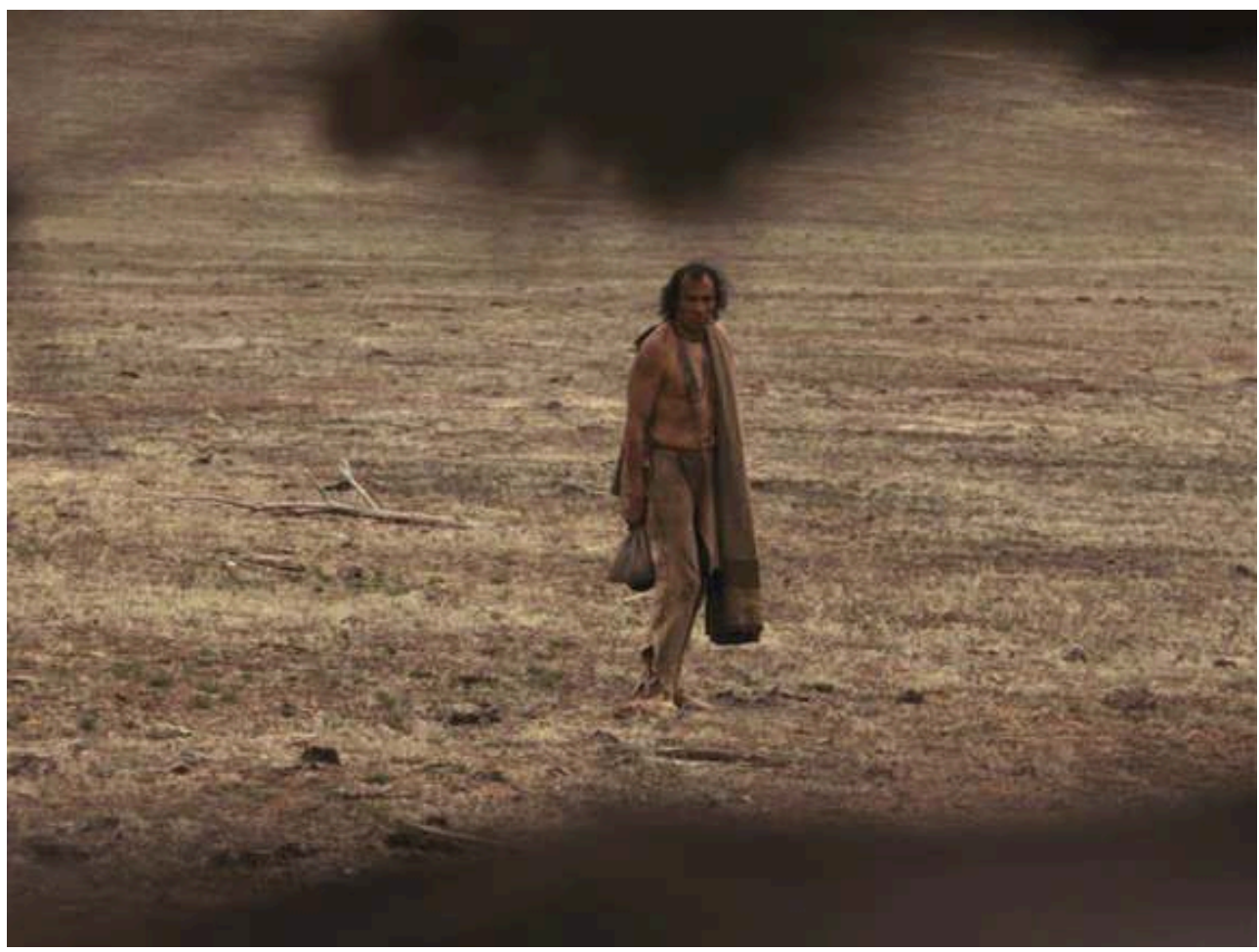

Emily's gaze on the "savage" is reframed by the branches of a half-dead tree.

\section{Cinéma-Vérité vs Myth on the Post-Colonial Frontera in Songs My Brother Taught Me and The Rider}

\section{Tensions between Myth and Social Realism}

Chloe Zhao's first two films foreground the tension between myth and reality in a similar way as Meek's Cutoff, although myth is here retained as a narrative element and driving motivation for the characters. The opening of The Rider, which focuses more directly on the mythology of the cowboy and rodeo culture, problematizes the tension between myth and reality as an aesthetic clash: the artificially lit, warmly colored, slow-motion, close-ups of a horse's body parts and shiny fur on the rodeo arena (Fig. 9) versus the natural light, cold color scheme, normal speed, of a wounded man waking up in a trailer home (Fig. 10). 
Fig. 9

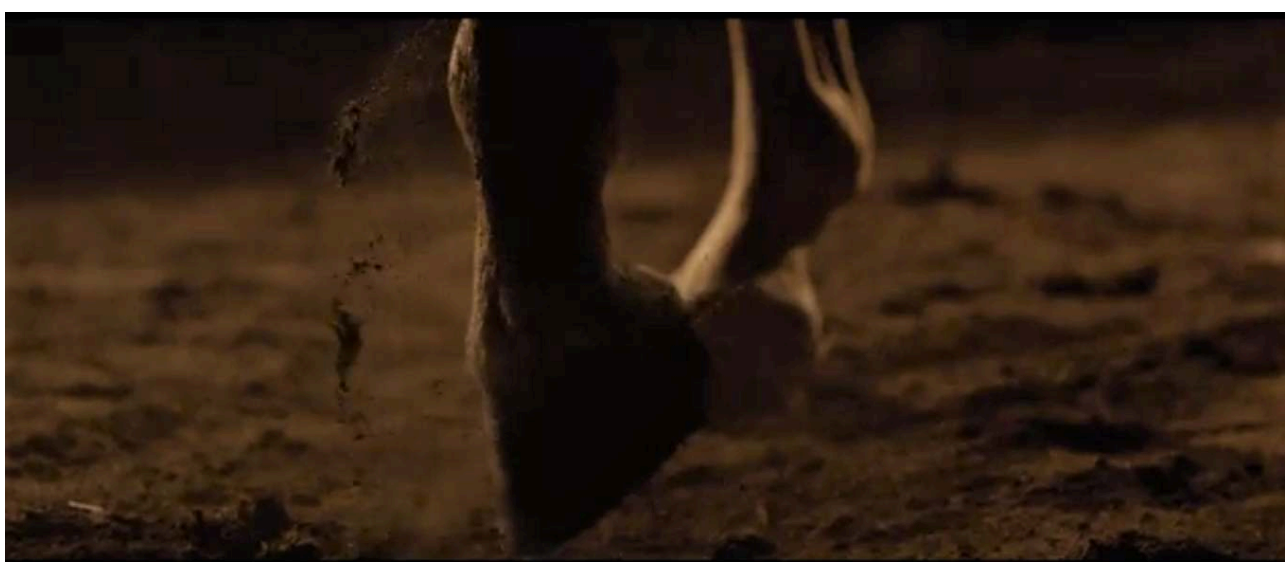

The artificially lit, warmly colored, slow-motion, close-ups of a horse's body parts.

Fig. 10

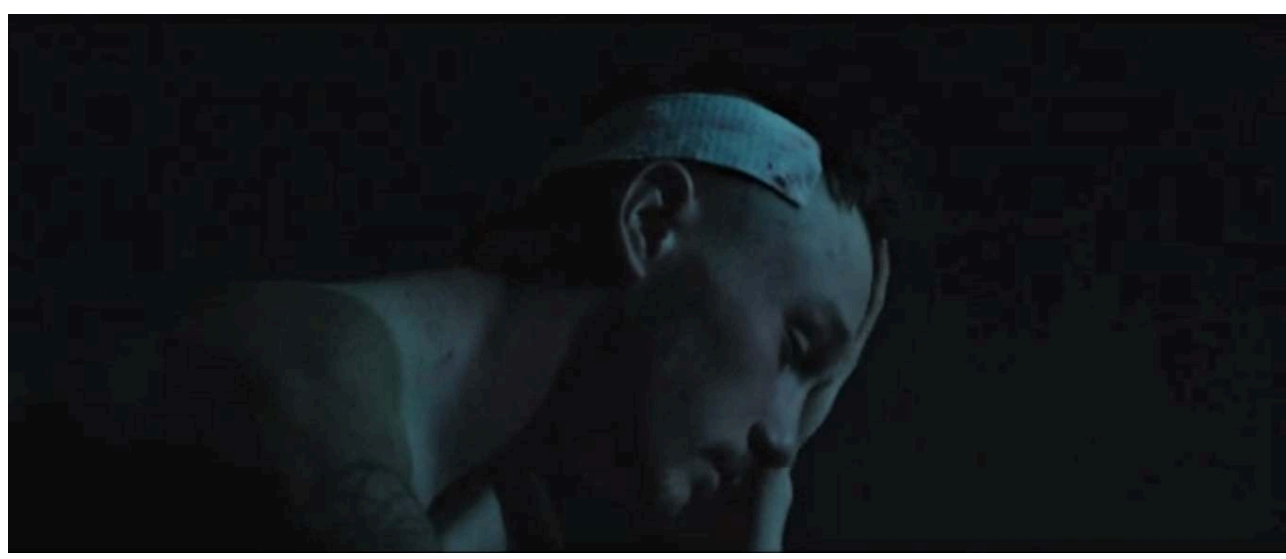

Natural light, cold color scheme shots of Brady waking up in his trailer.

The horse sequence is thus framed as a dream, its sleek aesthetic an indication of the myth's capacity to distort perception and fuel desire, its fragmented approach to the horse's body and blurred evocation of spectacle a recognition of the partial nature of a mesmerized gaze. This establishes the central narrative tension for the whole film, with a character drawn by an irresistible force to the practice of rodeo even though that practice is shown to be brutally violent to the riders' bodies and may cost the character his life.

Myth is retained in The Rider as in Songs through the main characters' special relationship with the Western landscape. Magic-hour cinematography is not given a foreboding quality as in Meek's, but preserves its mythical dimensions, here played out through beautifully balanced shots of characters looking at the desert landscape in embedded contemplation (Fig. 11). What Zhao stages, in these sequences, is the sacred wilderness of the transcendentalists, the wilderness as a place of revelation where human beings come closest to hearing God. One can suspect that the director was herself influenced by such mythical images of the West, since she described herself in interviews as an urbanite feeling stuck in the big cities; she even added, "When you're stuck historically you go west" (Tartaglione 2017). What drew her to South Dakota was the feeling of being connected with a past unchanged, a contrast to the rapidly 
changing urban China the director grew up in. Zhao welcomed the change as refreshing and eye-opening. Such an attitude towards the rural West may stem from yet another cliché attached to the region and its people as being closer to primitive truths and natural roots, and thus offering a source of regeneration.

Fig. 11

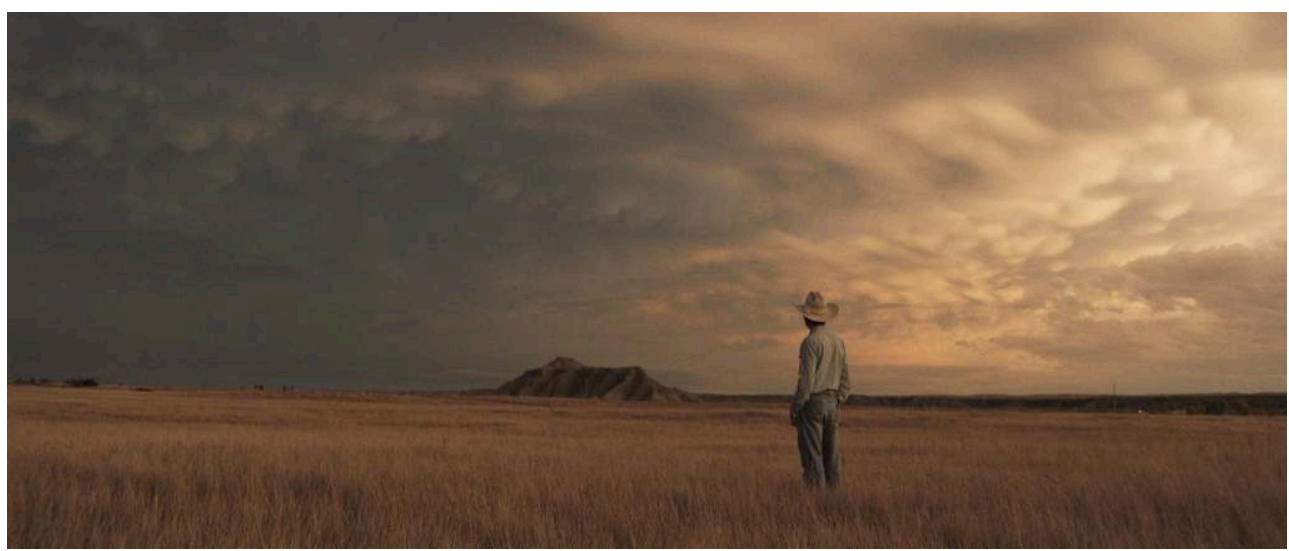

The Western landscape preserves its mythical dimensions in The Rider.

However, the characters who connect with the landscape are not the indianized whites of the revisionist Western or road movies, but are Native Americans. The focus is not the white gaze on virgin lands that need conquering but the Native intimacy to a land he or she loves, understands and inhabits. The mythic imagery of the West is still present, Western landscapes and an esoteric connection to them are still celebrated, but the myth has been appropriated and redefined by the indigenous population at the center of the narrative. The native Westerners of Zhao's films embrace the Western desert as their home, and their connection with it is intimate as much as historical, for instance through generational transmission from the old-timers seen in Songs. One scene in Songs explicitly rewrites the mythical iconography of the sunset from a postcolonial perspective by connecting it to Native American revival; Oglala artist Travis, obsessed with the number 7, explains its importance in the Bible and Oglala culture, and identifies the young Jashaun with the first generation of renewal since the Indian wars of the $19^{\text {th }}$ century (Fig. 12). Zhao's films thus participate in the decolonization of Western mythology by having indigenous characters redefine its meaning. 
Fig. 12

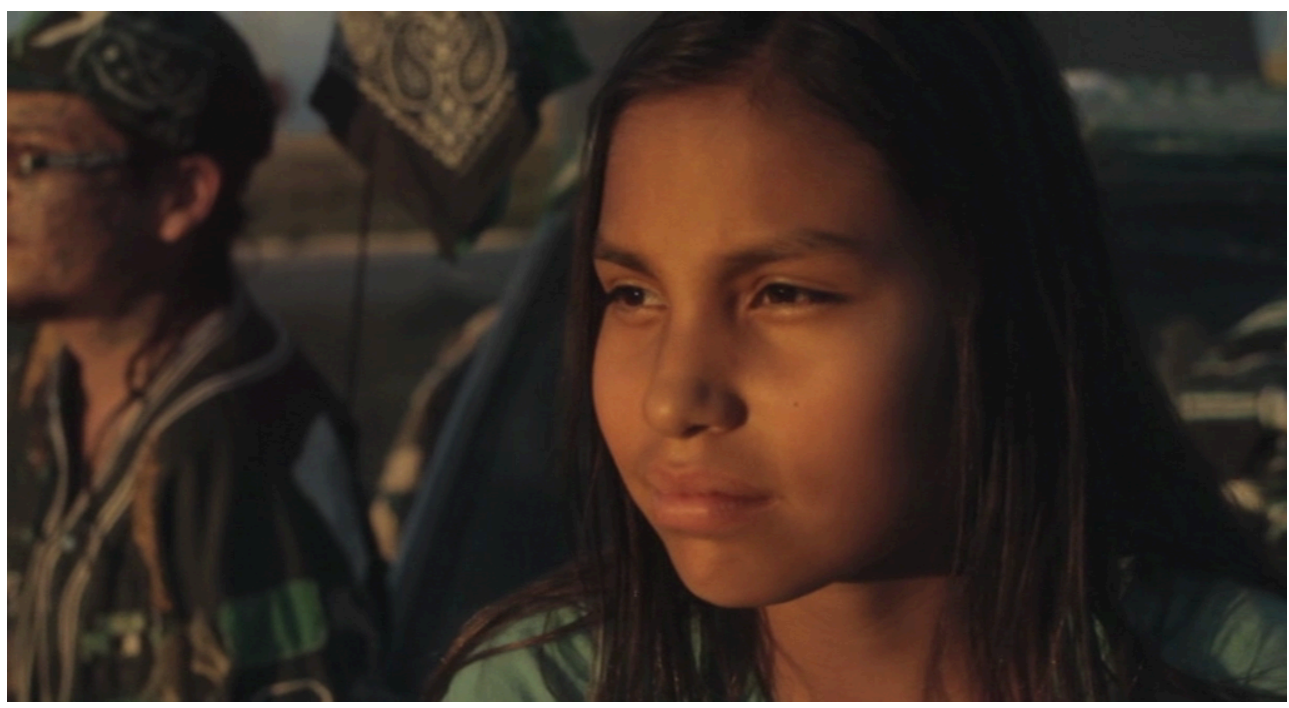

Jashaun's face; Songs rewrites sunset iconography from a postcolonial perspective.

31 This rewriting of the Western landscape's mythical qualities as the place of Native American regeneration is balanced with a docu-fiction, ${ }^{23}$ social realist approach to life on a present-day reservation. Zhao's films are striking, first and foremost, because of their incredible power as cinéma vérité. Non-professional actors were hired to play fictionalized versions of themselves on sets, which are marginally tampered versions of their living and working places. The epitome of the confusion between documentary and drama is encapsulated in a sequence of The Rider, when the character of the wounded rodeo rider is shown watching the real-life YouTube video of the actor's rodeo accident, which happened only five months before shooting (Erbland 2017). Fiction is foregrounded by a sustained musical score, classical narrative structure and careful visual compositions, but the raw materiality of the filmic world seeps through every shot in their sustained attention to textures, bodies and faces (Fig 13). Where Meek's Cutoff refused access to the interiority of its characters, Zhao's films build a striking intimacy with theirs, scrutinizing their expressions and movements for signs of strength or vulnerability. Emotional investment in the story is deep, reinforced by the constant movement of the handheld camera. The films' politics devolve from the empathy for the marginalized they strive to elicit. 
Fig. 13

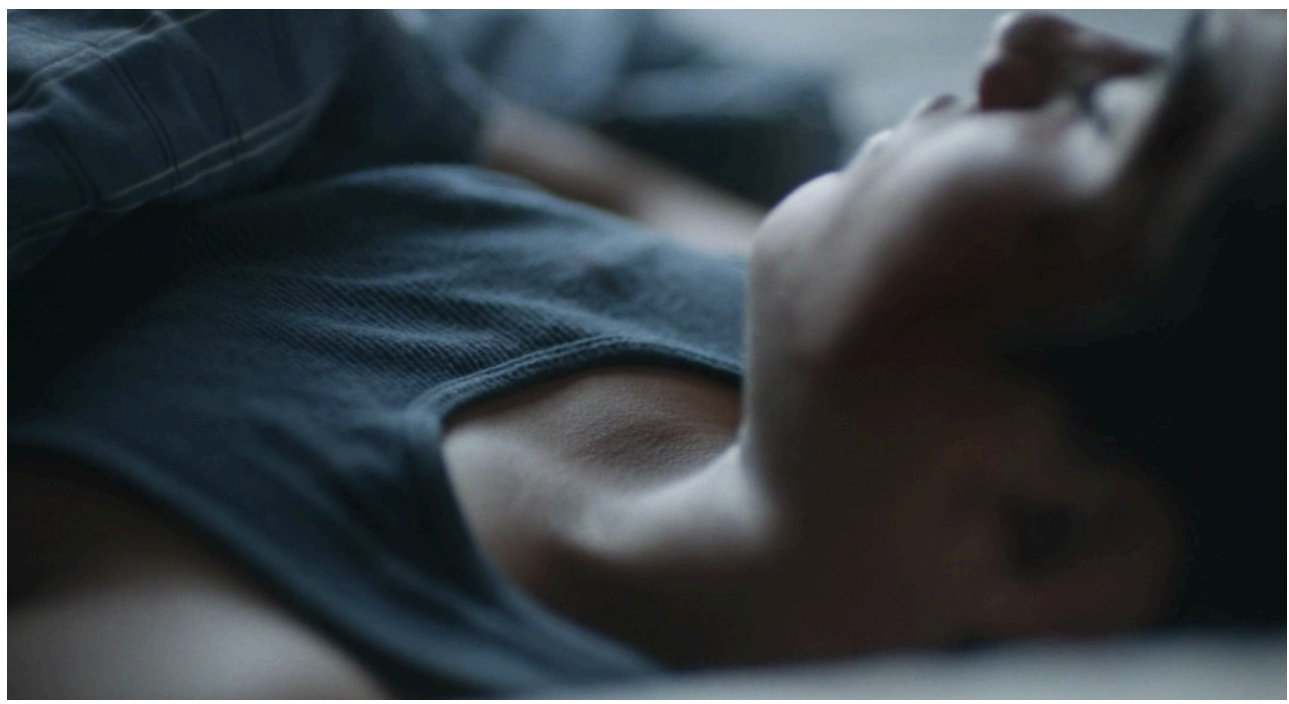

Sustained attention to textures, bodies and faces; Johnny waking up in Songs.

Zhao was interested in exploring "a part of the country demonized for probably voting for Trump, but," she adds, "they are humans" (Tartaglione 2017). This expression of humanist sentiments blended with socio-political concerns can be seen in the way she engages with her material. Realism, in Zhao's films, has a strong social dimension. Life in trailer parks surviving on low-paying jobs and smuggling, families turned dysfunctional by the toll of poverty and alcohol, social perspectives among the youth limited by their environment, and, more frontally in Songs, cultural genocide and revival among Native American communities (Fig. 14), are documented with tactful sympathy. Judgments are never laid on mothers abandoning their children or young riders risking their lives for a show. The absence of narrative contextualization invites the viewer to adopt an open-minded view, accepting things as they present themselves, reconstructing a coherent filmic world rather than laying judgment upon it. Camera positions that alternate distant and close shots, combined with shallow focus composition and a sustained use of racking focus to direct the gaze, construct a form of empathetic observation that serves to level social and cultural differences between viewers and characters. 
Fig. 14

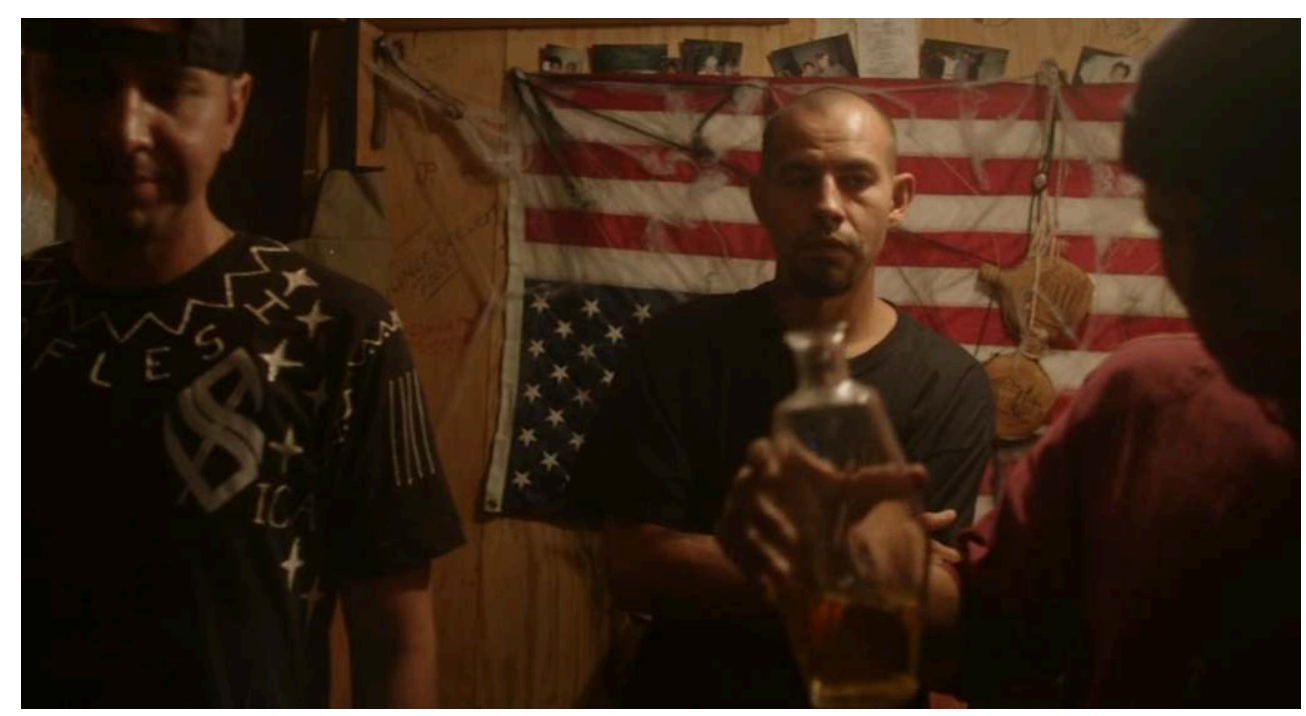

Social realism in Songs and the politics of Native American communities.

\section{The Politics of the Frontera}

Zhao referred to The Rider as "my version of a feminine gaze on one of the most masculine images in American culture" (Tartaglione 2017). Gender is certainly one of the central concerns of her films. The character of Jashaun in Songs is a gender hybrid full of transformative potential. Through costuming (her father's riding jacket, pig's mask to pass as older or ceremonial dress) and social practices (boxing with her brother and painting her toenails with a friend while donning a mustache, Fig. 15), she reveals the constructed nature of identity and embraces the freedom to compose one's self by performing across normative gender roles (Ben-Youssef 2018). The character of Brady in The Rider struggles as well with gender roles, in the form of the masculine cowboy icon which he strives to emulate against his own vulnerability and sense of community. Zhao's films treat gender as a construct and document their characters' strategies of negotiation between, under and across gender norms. The result is a queering of gender categories, which gives characters their subtle psychological complexity. 
Fig. 15

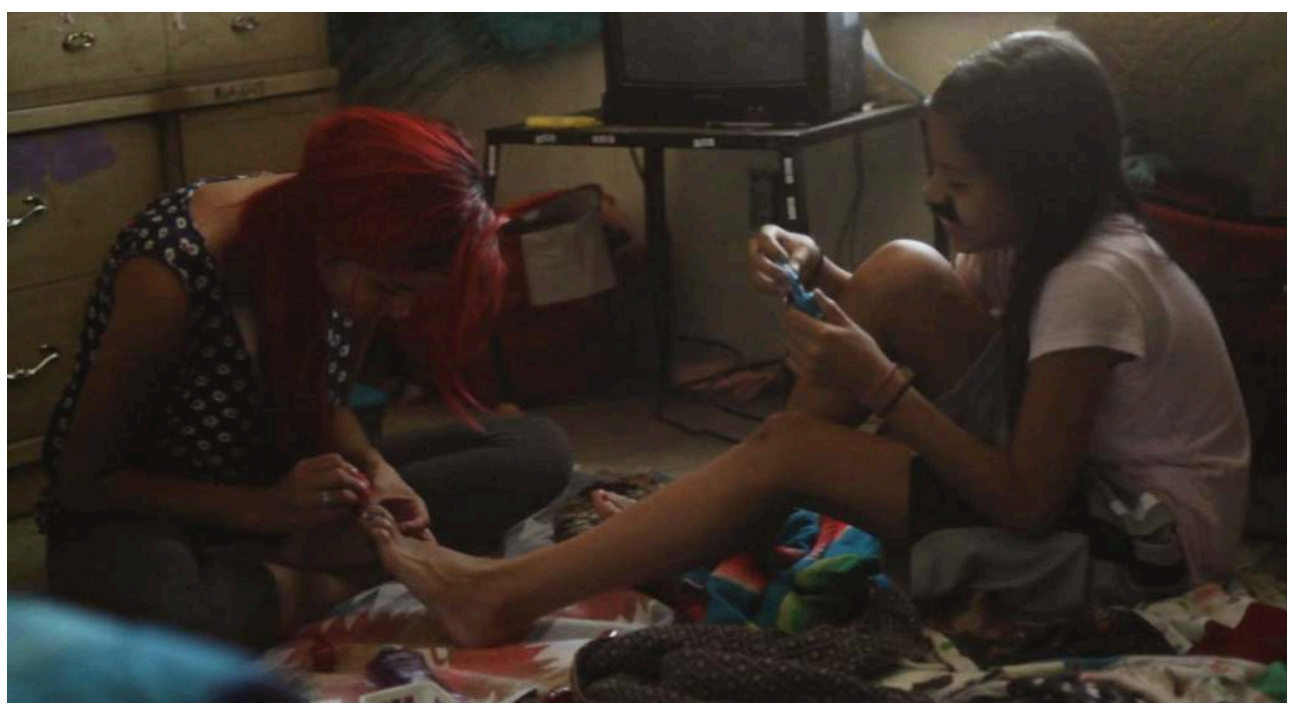

Jashaun paints her toenails with a friend while donning a mustache; cross-gender play. way Zhao's films treat race and culture. As Zhao expressed in interviews for a French blog, "you know, the cowboys we see in The Rider have Native blood as well. The characters in both my films live on the same reservation. To me it's not about the color of the skin, I mean they all live together, but it was interesting for me to show both sides" (Wagner 2017). For The Village Voice, the director more clearly emphasized the Sioux identity of her cowboy characters in The Rider, although many of them look white (Eribi 2017). At first glance, one may be tempted to distinguish between the films in terms of their overall perspective on the reservation. Songs adopts a more Native American perspective, with strong political commentary on neocolonial violence, while The Rider explores the fascination for a culture historically associated with white colonialism. Both films, however, construct the reservation as a frontera where races and cultures not only meet, but are mixed and acculturated to the point of indistinction.

Zhao is not interested in labels, and the style of her films works to soften racial and cultural lines. The absence of narrative contextualization prevents preconceived categories to determine the viewer's reception of the film, while the handheld camera expresses the blurring of boundaries in the unstable or fluid relation between on- and offscreen. Such instability largely participates in the psychological characterization (for instance, when Jashaun visits the burnt remnants of her father's house, or when Brady wakes up in the middle of the night to look at his head injury in the mirror), while fluid movements build up a sense of community (for instance, in the scenes connecting Jashaun and her brother Johnny to the landscape in Songs, or the moments of camaraderie preceding the campfire scene of The Rider); it also works to destabilize the limits of the frame and open onto holistic perspectives (e.g., the embers of campfires or desert dust elevating and disappearing into the air at key moments in Songs, Fig. 16). In addition to these poetic elements, what allows Zhao to rewrite the frontier myth in a progressive and inclusive way is, again, the construction of characters that transcend and explode colonial categories. 
Fig. 16

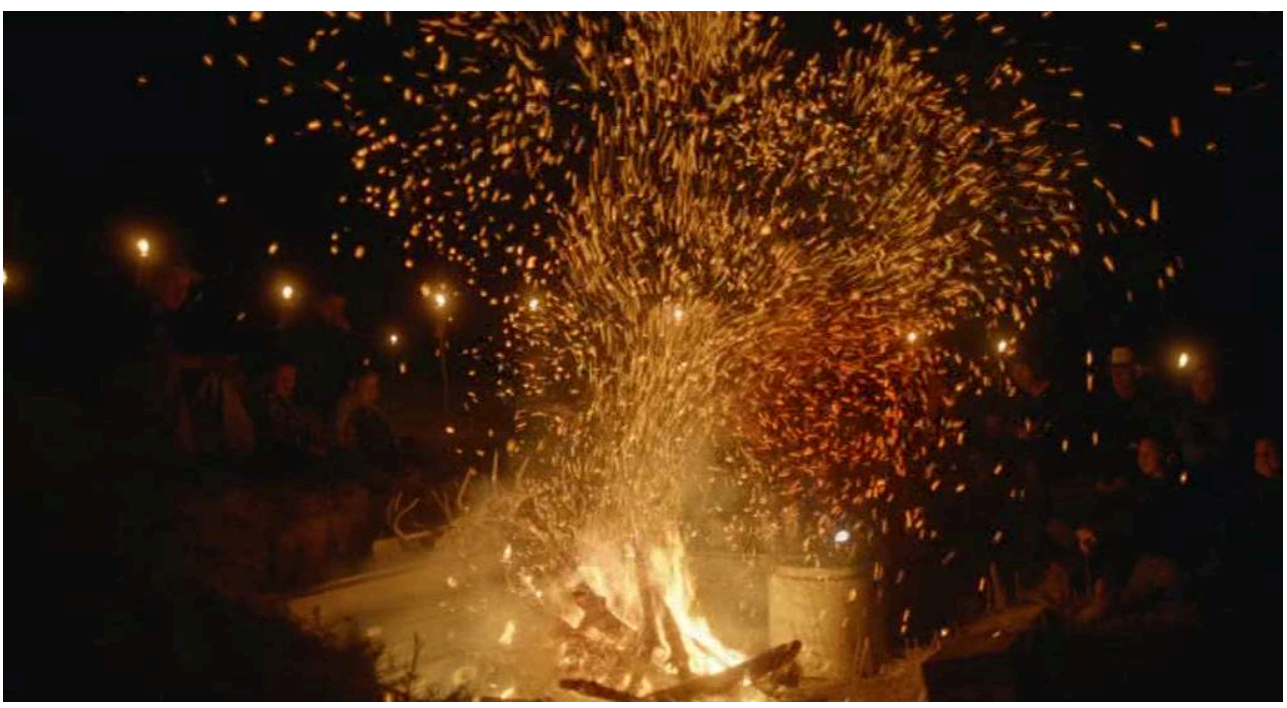

THE EMBERS OF CAMPfIRES ELEVATE INTO AIR IN SONgS WITH HANDHELD CAMERA PANNINg UP.

In Songs, Oglala children dream of becoming bull riders and Oglala men sing cowboy songs and revere rodeo stars, while the same community sustains local hip hop artists celebrating life on the Rez. Funerals are organized in Christian churches, and burials are performed by the same congregation to the sound of Oglala songs (Fig. 17). Illegal concerts offer both heavy metal and a cappella tribal songs. The young Jashaun blossoms in performing tribal dances in her ceremonial dress, but it is the pop music hit of the time that brings her closer to her brother. In The Rider, cowboys look white yet they spontaneously sing an Oglala song at a bonfire reunion. Rodeo allegedly comes from white folklore, but it is here practiced, watched and celebrated by the residents of the reservation. Despite the painful efforts of white historians and storytellers to erase the Hispanic origins of cowboy culture, The Rider suggests that this culture belongs to anyone who wants to make it their own. And above all, if there are differences in tone and focus between Zhao's two films, they are bridged in that they both document one same and single place, the Pine Ridge reservation, with shooting locations such as the rodeo arena and the badlands and actors playing secondary characters visible in both. Between races, cultures and stories, lines are blurred, so that the American West regains, in Zhao's films, its complex and dynamic identity as a frontera. 


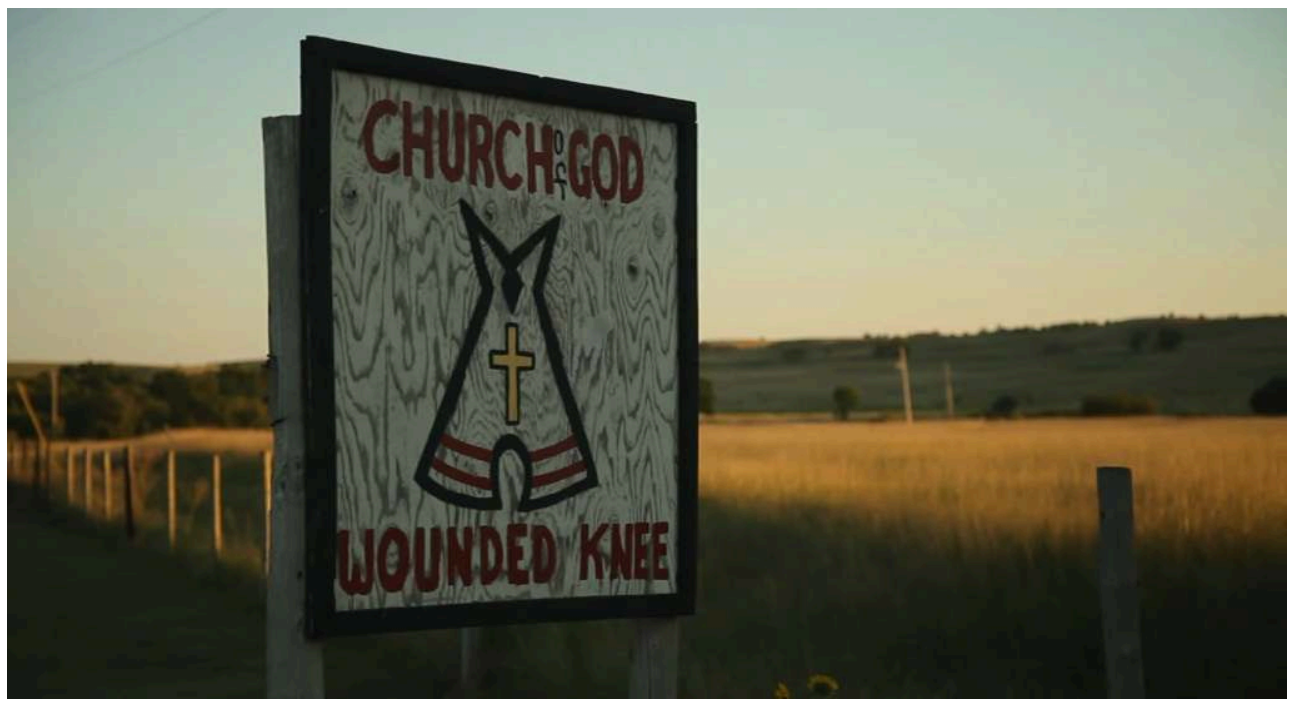

Oglala churches; the Pine Ridge reservation as a frontera.

\section{Conclusion}

Meek's Cutoff and Zhao's films are successful rewritings of imperial frontier narratives because, each in their own way, they stage and transcend the limits of the strategies historically adopted to perform these rewritings. Avoiding the pretention of an allencompassing Other perspective on the history of the West, or the soothing narrative of a cross-racial alliance against white male supremacy, Meek's Cutoff seeks the humility, sincerity and self-awareness a progressive approach to the history of the American West should be grounded in. With a blend of harsh realism, anti-triumphalism, slow cinema and a female perspective conscious of its limitations, the film rewrites the frontier narrative as a story full of questions and possibilities. Rather than certainty and triumphalism, we are given caution and undecidability, which is probably the closest to what settlers experienced in the $19^{\text {th }}$ century West, and demonstrates an acute sensibility to the layered complexity of identity politics. In disregarding the fixed categories of identity politics and in presenting the contemporary West as a site of gender hybridity and racial fluidity, Songs My Brother Taught Me and The Rider redeem the frontier myth of its imperial trappings and rewrite the marginal West as a place with transformative potential. The icons of Western mythologies-the sunset, the cowboy, the Western landscape-are appropriated and redefined by native characters, thus participating in the decolonization of the national imaginary. All three films resort to the major revisionist strategies of post-Western cinema-alternative perspectives and trajectories; historical or social realism; and dynamic identities-but balance and perfect them through limited perception, recognition of the power of myth, or mise en abyme of identity construction. Reichardt's film does not challenge the fixed structures of opposed identities on the Western frontier, but seeks, rather, to reveal the intricate hierarchies of race and gender at play in the power structure of imperial conquest. Zhao's films embrace a postcolonial perspective on the contemporary West as a product of Western colonization, yet a place that transcends the binary oppositions of imperialism historically inscribed upon it. As films whose 
critical gazes emerge from the margins of American film production, they provide a decentered and eventually empowering perspective on the imperial politics of Western mythology.

\section{BIBLIOGRAPHY}

Anzaldúa, Gloria. Borderlands / La Frontera: The New Mestiza. San Francisco: Aunt Lute Books, 1987. Aron, Stephen. "Lessons in Conquest: Towards a Greater Western History." Pacific Historical Review 63:2 (1994): 125-147.

Benoliel, Bernard and Jean-Baptiste Thoret. Road Movie, USA. Paris: Hoëbeke, 2011.

Ben-Youssef, Fareed. “Just Make Me Look Good: The Duel Against Mythic Representation in the Transnational Western Films of Chloé Zhao." Paper presented at the conference

"Transnationalism and Imperialism: New Perspectives on the Western." Université Paul Valéry Montpellier 3, 16 November 2018.

Berra, John. Declarations of Independence: American Cinema and the Partiality of Independent Production. Bristol: Intellect Books, 2008.

Brereton, Pat. Hollywood Utopia: Ecology in Contemporary American Cinema. Bristol: Intellect Books, 2005.

Carter, Mathew. Myth of the Western: New Perspectives on Hollywood's Frontier Narrative. Edinburgh: Edinburgh University Press, 2014.

Campbell, Neil. Post-Westerns: Cinema, Region, West. Lincoln: University of Nebraska Press, 2013.

Campbell, Neil. The Rhizomatic West, Representing the American West in a Transnational, Global, Media Age. Lincoln: University of Nebraska Press, 2008.

Cohan, Steven and Ina Rae Hark (eds.). The Road Movie Book. New York: Routledge, 1997.

De Luca, Tiago. Realism of the Senses in World Cinema: The Experience of Physical Reality. New York: I.B. Tauris, 2014.

Erbland, Kate. "The Rider Review: This Cannes Winner is Part Truth, Part Drama, and Completely Heartrending," October 13, 2017. https://www.indiewire.com/2017/10/the-rider-review-chloecannes-winner-1201887010/. Accessed on 20 March 2019.

Eribi, Bilge. “This Is Not Your Last Rodeo." Village Voice, 21 May 2017. Accessed on 18 December 2018.

https://www.villagevoice.com/2017/05/21/this-is-not-your-last-rodeo/.

French, Philip. Westerns: Aspects of a Movie Genre. London: Secker \& Warburg, 1973.

Gorfinkel, Elena. "Exhausted Drift: Austerity, Dispossession and the Politics of Slow in Kelly Reichardt's Meek's Cutoff." In Slow Cinema. Ed. Tiago de Luca et al.. Edinburgh: Edinburgh University Press, 2015. 123-136. 
Kitses, Jim. "Introduction: Post-Modernism and The Western." In The Western Reader. Ed. Jim Kitses et al. New York: Limelight Editions, 1998. 15-34.

Klinger, Barbara. “The Road to Dystopia; Landscaping the Nation in Easy Rider." In The Road Movie Book. Ed. Steven Cohan et al.. New York: Routledge, 1997. 179-203.

Laderman, David. Driving Visions: Exploring the Road Movie. Austin: University of Texas Press, 2002.

Kois, Dan. "Eating Your Cultural Vegetables," The New York Magazine, April 29, 2011.

https://www.nytimes.com/2011/05/01/magazine/mag-01Riff-t.html. Accessed on 18 December 2018.

Limerick, Patricia Nelson and Richard White. The Frontier in American Culture: An Exhibition at the Newberry Library, August 26, 1994-January 7. Chicago: Newberry Library, 1994.

Natali, Maurizia. "The Course of Empire: Sublime Landscapes in the American Cinema”. In Landscape and Film Martin Lefebvre. New York: Routledge, 2007. 91-123.

Pratt, Mary Louise. Imperial Eyes: Travel Writing and Transculturation. London and New York: Routledge, 1992.

Pratt, Mary Louise. Imperial Eyes: Travel Writing and Transculturation. New York: Routledge, 1992. Sarris, Andrew. The American Cinema: Directors and Direction, 1929-1968. New York: Da Capo Press, 1968.

Slotkin, Richard. Gunfighter Nation: The Myth of the Frontier in Twentieth-century America. Norman: University of Oklahoma Press, 1998.

Tartaglione, Nancy. "The Rider Helmer Chloe Zhao On Her Portrait Of the Demonized American Heartand," Deadline, May 20, 2017. Accessed on 18 December 2018.

https://deadline.com/2017/05/the-rider-chloe-zhao-cannes-directors-fortnight-protagonistpictures-ones-to-watch-clip-video-1202090289/

Wagner, Julien. "Rencontre avec Chloe Zhao," Grand Écart, May 23, 2017. Accessed on 18 December 2018.

http://www.grand-ecart.fr/portraits/the-rider-rodeo-brady-jandreau-interview-chloe-zhaocannes-2017/

White, Patricia. "Pink Material: White Womanhood and the Colonial Imaginary of World Cinema Authorship." In The Routledge Companion to Cinema and Gender. Ed. Kristin Lené Hole et al. New York: Routledge, 2017. 215-226.

White, Richard. The Middle Ground: Indians, Empires, and Republics in the Great Lakes Region, 1650-1815. Cambridge: Cambridge University Press, 1991.

\section{NOTES}

1. According to Richard Slotkin's analysis of the myth of the frontier in $20^{\text {th }}$ century American culture, Westerns are "storyforms whose connection to the characteristic images, characters, and references of frontier mythology is observably direct" (25).

2. Stephen Aron: "Reconfigured as the lands where separate polities converged and competed, and where distinct cultures collided and occasionally coincided, the frontier unfolds the history of the great West in ways that Turner never imagined" (128).

3. Slotkin: "In 1893 the Frontier was no longer (as Turner saw it) a geographical place and a set of facts requiring a historical explanation. Through the agency of writers like [Frederick Jackson] 
Turner and [Theodore] Roosevelt it was becoming a set of symbols that constituted an explanation of history. Its significance as a mythic space began to outweigh its importance as a real place, with its own peculiar geography, politics, and cultures" (61).

4. The term first emerged in Philip French's seminal book on the Western, Westerns: Aspects of a Movie Genre, in 1973. For a detailed discussion of the term and its aesthetic and political implications, see the introduction to Neil Campbell's Post-Westerns: Cinema, Region, West.

5. The influential American critic Andrew Sarris was the standard-bearer of auteur cinema in the US from the 1960 s to the 1980 s, starting with his 1968 publication on

6. See David Laderman's conception of the road movie as essentially linked to subversion, "explor[ing] the 'borders' (the status quo conventions) of American society" (2), a genre whose "core of rebellion and cultural critique becomes greatly enhanced and expanded" when "driven by drivers previously consigned to the sidelines". (179).

7. By the 1960s, the Western, road movie, and American cinema in general developed a "growing preoccupation with native Americans as a source of ecological agency. [...] The American Indian 'other', in spite of remaining firmly in the background within the dominant Hollywood genres, has nonetheless become a primary focus for progressive ecological values" (Brereton 98-99). Maurizia Natali defines this particular film as a "New Age narrative of 'spiritual healing"' (120).

8. Steven Cohan and Ina Rae Hark: "After Thelma \& Louise, Hollywood began to recognize again the increasing hospitality of the road to the marginalized and alienated - not only women (Leaving Normal), but also gays (My Own Private Idaho, The Living End, To Wond Foo, Thanks for Everything!, Julie Newmar), lesbians (Boys on the Side, Even Cowgirls Get the Blues), and people of color (Get on the Bus, Fled, Powwow Highway) - and to renew the road's historical currency" (12).

9. A post-Western, in the words of director Ang Lee, is a film in which "the viewer has to rethink the parameters of the Western, adjust its 'frame,' to comprehend the inclusion of [the male characters'] desire" (Campbell, The Rhizomatic West 180).

10. See Robert Ray's observation about what he called the Left movies of the late 1960s and 1970s: "The Left movies that superficially acknowledged the invalidation of western lifestyles and values typically glorified the very myths they appeared to disown" (310).

11. Barbara Klinger: "Through its vast, unpopulated, unmodernized, romantic vistas of natural Western glories, the film unquestioningly supports one of the foundations of American ideology - frontierism - a myth that had become a virtual lingua franca in traditional nationalistic discourses in the late 1960s" (192).

12. Road movies are especially prone to such directional reconfigurations, as illustrated by the maps of narrative trajectories opening each chapter in Bernard Benoliel and Jean-Baptiste Thoret's Road Movie, USA.

13. Discussing Easy Rider and Kes (Ken Loach, 1969), John Berra writes that "these were cinematic works that sought to reach new levels of social-realism by integrating production method with subject matter, resulting in the absorption of the audience in an acute filmic depiction of reality. [...] Such methods created a new form of film production, one that would come to be termed 'independent' for both its unique aesthetic approach, and its socio-political thinking." (12). Focusing on the American road movie of the New Hollywood, Laderman further notes that it "imports the following from postwar European film modernism: elliptical narrative structure and self-reflexive devices; elusive development of alienated characters; bold traveling shots and montage sequences" (5).

14. Borrowed from Mary Louise Pratt. Pratt defines the contact zone as "the space of colonial encounters, the space in which peoples geographically and historically separated come into contact with each other and establish ongoing relations, usually involving conditions of coercion, racial inequality, and intractable conflict" (6).

15. The expression "middle ground" was coined by historian Richard White (1991) to designate the meeting space of peoples and cultures in North America during the colonial period.. 
16. As defined and described in the seminal, hybrid essay by Gloria Anzaldúa, Borderlands / La FronteraErreur ! Signet non défini.: The New Mestiza.

17. This film celebrates a joint rescue by Indians and a trapper of a white girl condemned to the stake by Puritan elders in colonial New England. In the ending scene, while the Indian chief and trapper shake hands on the body of the white female who will wed the white man, her gaze is set on the native body, full of repressed desires and possibilities.

18. Mathew Carter: "[Three Burials] explodes the notion of a border through its presentation of the various characters and their relationships, all of whom cross 'borders' of one kind or another: racial, marital, lawful, political, social, economic and cultural" (185).

19. Randy Gragg, "Interview with Screenplay Writer Jon Raymond," in the Preliminary Press Notes to Meek's Cutoff, Oscilloscope Laboratories, (4).

20. Introducing his discussion of the works of Carlos Reygadas, Tsai Ming-liang and Gus Van Sant, Tiago de Luca observes that what he calls a new realist aesthetic is "steeped in the hyperbolic application of the long take, which promotes a sensuous viewing experience anchored in materiality and duration" (1).

21. Preliminary Press Notes to Meek's Cutoff, Oscilloscope Laboratories (3).

22. Ibid.

23. In the sense that it blends documentary and fiction at the stylistic and narrative levels. Zhao's films are firmly and explicitly grounded in fiction, but their material has strong ties to real people, locations and events.

\section{ABSTRACTS}

This article discusses Kelly Reichardt's Meek's Cutoff (2010) and Chloe Zhao's Songs My Brother Taught Me (2015) and The Rider (2017) as contemporary rewritings of the Western genre and frontier mythology. I argue that the three films play the mythologies of the American West against the realities and consequences of settler colonialism, provide alternative perspectives on the politics of empire, construct the Western frontier as a contact zone, and challenge the original epic story of linear conquest by redefining what it means to travel or live in the Great American desert. I also underline how these films differ in their preferred focus for cultural and political rewriting: Meek's Cutoff mainly centers on its alternative feminine perspective and on a deflation of the myth in its original historical terrain, while Zhao's films are more about producing a postcolonial perspective on the contemporary West as a marginalized yet fascinating frontera.

Cet article analyse La Dernière piste (Meek's Cutoff, Kelly Reichardt, 2010), Les Chansons que mes frères m'ont apprises (Songs My Brother Taught Me, Chloe Zhao, 2015) et The Rider (Chloe Zhao, 2017) comme des exemples contemporains de réécritures cinématographiques du genre du Western et du mythe de la Frontière. J'y montre que les trois films révèlent l'histoire de la colonisation derrière les mythes de l'Ouest, proposent une perspective alternative sur l'impérialisme américain, construisent l'Ouest comme une zone de contact et concurrencent le récit épique d'une conquête linéaire en envisageant la traversée du désert américain autrement. Je distingue également les trois films par les stratégies de réécriture préférées : Meek's Cutoff se concentre sur la construction d'une perspective alternative féminine dans l'Ouest historique $d u 19^{\mathrm{e}}$ siècle, 
tandis que les films de Zhao produisent une perspective contemporaine sur l'Ouest comme un espace postcolonial marginal autant que fascinant.

\section{INDEX}

Keywords: Western, West, frontier myth, myth, frontier, history, imperialism, ideology, United States, independent cinema, cinema

Mots-clés: histoire, mythe, western, États-Unis, Ouest, mythe de la frontière, frontière, impérialisme, politique, cinéma indépendant, cinéma

\section{AUTHOR}

\section{HERVÉ MAYER}

Maître de conférences

Université Paul Valéry Montpellier 3

hervmayer@gmail.com 